\title{
Pengaruh Pendidikan Kesehatan Keluarga terhadap Kemampuan Keluarga Merawat Klien HDR di Kota Tasikmalaya
}

\author{
Ridwan Kustiawan
}

\begin{abstract}
Abstrak
Videbeck (2008) mengatakan bahwa tanda negatif pada skizofrenia akan menetap lebih lama pada klien. Gejala negatif seringkali tidak disadari oleh pihak keluarga, karena dianggap tidak mengganggu. Salah satu tanda gejala negatif yang sering ditemukan adalah HDR. Penelitian bertujuan mengetahui pengaruh pendidikan kesehatan keluarga terhadap kemampuan keluarga merawat klien HDR di Kota Tasikmalaya. Penelitian ini dengan desain quasi eksperimen pendekatan pre post tes dengan grup kontrol. Responden penelitian adalah keluarga dengan koping keluaga tidak efektif dalam merawat klien HDR, 50 keluarga dibagi 2 kelompok yaitu 25 kelompok intervensi dan 25 kelompok kontrol. Kemampuan keluarga merawat klien HDR yang mendapatkan pendidikan kesehatan keluarga lebih tinggi dibandingkan dengan kelompok yang tidak mendapatkan pendidikan kesehatan keluarga. Disarankan pendidikan kesehatan keluarga digunakan sebagai terapi keluarga dalam meningkatkan kemampuan keluarga merawat klien dengan HDR.
\end{abstract}

Kata Kunci: Kemampuan Keluarga, Klien harga diri rendah, Pendidikan kesehatan keluarga.

\begin{abstract}
Videbeck (2008) stated that the negative symptoms of schizophrenia would be more permanent to the client. Negative symptoms ussually were not perceived by the family, because of disturbances behaviours. The purpose of this research was to identify the effects of family psychoeducation therapy towards the family ability to take care of the client with low selfesteem in Tasikmalaya. This research utilized quasi experimental design using pre and post test with control group. The respondents consisted of families with ineffective coping in caring for low self-esteem clients, fifty families were divided inti 2 groups; 25 families as experimental group and 25 families as control group. The research result demonstrated that the families who received health education showed that the higher ability as compored to families without health education. It was recommended that health education would be used in family therapy for inproving the family ability to care for the clients with a low self-esteem.
\end{abstract}

Keywords: family ability, client low self esteem, health education

\section{PENDAHULUAN}

Stuart \& Laraia (2005), mengatakan perilaku yang sering muncul pada klien skizofrenia antara lain: motivasi kurang $(81 \%)$, isolasi sosial $(72 \%)$, perilaku makan dan tidur yang buruk (72\%), sukar menyelesaikan tugas (72\%), sukar mengatur keuangan $(72 \%)$, penampilan yang tidak rapi/bersih (64\%), lupa melakukan sesuatu $(64 \%)$, kurang perhatian pada orang lain (56\%), sering bertengkar (47\%), bicara pada diri sendiri $(41 \%)$, dan tidak teratur makan obat (40\%). Penjelasan ini dapat diartikan bahwa pada klien dengan skizofrenia mengalami penurunan motivasi yang tinggi dan sukar menyelesaikan tugas. Hal ini disebabkan karena pasien merasa tidak mempunyai kemampuan lagi, merasa lebih rendah dari orang lain sehingga berdampak pada isolasi sosial. Perilaku yang muncul pada harga diri rendah kronik diantaranya merusak diri dan orang lain, gangguan berhubungan dan menarik diri dari realitas, 
sehingga apabila tidak ditangani dapat menyebabkan depresi bahkan lebih jauh dapat melakukan tindakan bunuh diri.

Berdasarkan penelitian Keliat (2006) ditemukan bahwa angka kekambuhan pada pasien tanpa terapi keluarga sebesar 25$50 \%$, sedangkan angka kambuh pada pasien yang diberikan terapi keluarga adalah sebesar $5-10 \%$. Berbagai upaya pengobatan dan teori model konsep keperawatan jiwa telah dilaksanakan, akan tetapi masih banyak klien yang mengalami perawatan ulang atau kekambuhan dan dirawat di rumah sakit jiwa. Menurut Sullinger (1988) dan Carson/Ros (1987) dalam Yosef (2007), klien dengan diagnosa skizofrenia diperkirakan akan kambuh 50\% pada tahun pertama, $70 \%$ pada tahun kedua setelah pulang dari rumah sakit, kekambuhan $100 \%$ pada tahun kelima setelah pulang dari rumah sakit karena perlakuan yang salah selama di rumah atau di masyarakat.

Masyarakat Tasikmalaya yang mengalami gangguan jiwa cukup banyak. Hal ini bisa dilihat dari rekam medik Rumah Sakit Umum (RSU) Kota tahun 2011 menunjukkan jumlah pasien yang kontrol ke poli jiwa RSU Kota Tasikmalaya sebanyak 6.437 orang, dengan kasus terbanyak setiap bulannya adalah skizofrenia.

\section{METODE PENELITIAN}

Desain yang digunakan dalam penelitian ini adalah "Quasi experimental pre-post test with control group" dengan intervensi pendidikan kesehatan keluarga. Penelitian dilakukan untuk mengetahui perbedaan kemampuan keluarga dalam memberikan cara perawatan pada klien gangguan jiwa dengan harga diri rendah kronik sebelum dan sesudah dilakukan pendidikan keluarga di Kota Tasikmalaya.

Populasi penelitian adalah seluruh keluarga dengan salah satu anggota keluarga mengalami gangguan jiwa dengan harga diri rendah di Kota Tasikmalaya. Sampel penelitian adalah keluarga yang mempunyai salah satu anggota keluarga yang mengalami gangguan jiwa dengan
Pendidikan kesehatan Keluarga adalah salah satu elemen program perawatan kesehatan jiwa keluarga dengan cara pemberian informasi, edukasi melalui komunikasi yang terapeutik. Program ini merupakan pendekatan yang bersifat edukasi dan pragmatis (Stuart \& Laraia, 2005). Carson (2000) menyatakan bahwa psikoedukasional merupakan suatu alat terapi keluarga yang makin populer sebagai suatu strategi untuk menurunkan faktorfaktor resiko yang berhubungan dengan perkembangan gejala-gejala perilaku. Contoh situasi yang tepat dari penerapan pendidikan kesehatan untuk keluarga menurut Carson (2000) adalah: 1). Informasi dan latihan tentang area khusus kehidupan keluarga, seperti latihan ketrampilan komunikasi atau latihan menjadi orang tua yang efektif. 2). Informasi dan dukungan terhadap kelompok keluarga khusus stress dan krisis, seperti pada kelompok pendukung keluarga dengan penyakit Alzheimer. 3). Pencegahan dan peningkatan, seperti konseling pra nikah, untuk keluarga sebelum terjadinya krisis. Penelitian ini bertujuan untuk mengetahui pengaruh pendidikan kesehatan keluarga terhadap kemampuan keluarga merawat klien HDR di Kota Tasikmalaya.

harga diri rendah kronik di Kota Tasikmalaya yang sesuai dengan kriteria inklusi. Didapat sampel 25 kelompok intervensi dan 25 kelompok kontrol.

Sebelum penelitian dilakukan, semua responden yang menjadi subyek penelitian telah diberi informasi tentang rencana, tujuan dan manfaat penelitian melalui pertemuan resmi dan tertulis. Setiap responden diberi hak penuh untuk menyetujui atau menolak menjadi responden dengan cara menandatangani informed concent atau surat pernyataan kesediaan yang telah disiapkan oleh peneliti. Etika penelitian terhadap subyek penelitian ini meliputi hak klien dihormati jika timbul respon negatif, privasi dihormati, 
anominitas dipertahankan. Data dari responden akan dijaga kerahasiaannya, akses hanya pada peneliti dan jika data tersebut sudah selesai digunakan maka data akan dimusnahkan.

Uji kesetaraan dilakukan untuk mengidentifikasi kesamaan variabel antara kelompok intervensi dengan kelompok kontrol. Uji kesetaraan dilakukan untuk mengidentifikasi kesetaraan karakteristik keluarga dan kemampuan keluarga dalam memberikan perawatan klien dengn harga diri rendah kronik antara kelompok kontrol dengan kelompok intervensi.

\section{HASIL PENELITIAN}

\section{Perbedaan kemampuan keluarga dalam merawat klien HDR sebelum dan sesudah mendapatkan pendidikan kesehatan keluarga}

Tabel 1. Uji kesetaraan karakteristik keluarga antara kelompok kontrol dengan kelompok intervensi sebelum pendidikan kesehatan keluarga di Kota Tasikmalaya

\begin{tabular}{|c|c|c|c|c|}
\hline No & Karakteristik keluarga & Kelompok kontrol & Kelompok intervensi & $P$ value \\
\hline \multirow[t]{3}{*}{1} & Usia & & & \\
\hline & 25-44 tahun & 3 & 8 & 0,231 \\
\hline & $>44$ tahun & 22 & 17 & \\
\hline \multirow[t]{3}{*}{2} & Pendidikan & & & \\
\hline & Rendah & 16 & 22 & 0,530 \\
\hline & Tinggi & 9 & 3 & \\
\hline \multirow[t]{3}{*}{3} & Pekerjaan & & & \\
\hline & Bekerja & 18 & 14 & 0,177 \\
\hline & Tidak bekerja & 7 & 11 & \\
\hline \multirow[t]{3}{*}{4} & Pendapatan & & & \\
\hline & Dibawah UMR & 12 & 15 & 0,226 \\
\hline & Diatas UMR & 13 & 10 & \\
\hline \multirow[t]{3}{*}{5} & Hubungan dengan klien & & & \\
\hline & Keluarga inti & 22 & 22 & 1,00 \\
\hline & Bukan keluarga inti & 3 & 3 & \\
\hline
\end{tabular}

Tabel 1. diketahui bahwa nilai $p$ value dari semua karakteristik klien lebih dari 0,05 artinya bahwa tidak ada perbedaan karakteristik keluarga antara kelompok kontrol dengan kelompok intervensi sebelum pelaksanaan pendidikan kesehatan keluarga.

Tabel 2. Uji kesetaraan kemampuan keluarga merawat klien HDR antara kelompok kontrol dengan kelompok intervensi sebelum pendidikan kesehatan keluarga di KotaTasikmalaya

\begin{tabular}{clllc}
\hline No. & \multicolumn{1}{c}{ Variabel } & Kelompok & Mean & P value \\
\hline \multirow{2}{*}{1} & Kemampuan keluarga & & & \\
& Kognitif & Intervensi & 23,46 & 0,321 \\
& Psikomotor & & 33,04 & \\
\hline \multirow{2}{*}{2} & Kognitif & \multirow{2}{*}{ Kontrol } & 27,54 & 0,545 \\
& Psikomotor & 33,04 & \multirow{2}{*}{}
\end{tabular}

Tabel 2. diketahui mean antara kelompok intervensi dengan kelompok kontrol tidak jauh berbeda. Nilai $p$ value kemampuan keluarga lebih dari 0,05 artinya bahwa tidak ada perbedaan antara kemampuan keluarga baik kognitif maupun psikomotor pada kelompok intervensi dan kelompok kontrol sebelum pemberian terapi pendidikan kesehatan keluarga. 


\section{Gambaran kemampuan keluarga dalam merawat HDR}

Tabel 3. Analisis perbedaan kemampuan kognitif dan psikomotor keluarga kelompok intervensi sebelum dan sesudah pendidikan kesehatan keluarga di Kota Tasikmalaya

\begin{tabular}{clcccc}
\hline No. & \multicolumn{1}{c}{ Variabel } & Mean & SD & Min-maks & P value \\
\hline 1. & Kemampuan Kognitif : & 41,28 & 5,82 & $33-61$ & \\
& Sebelum & 70,48 & 2,45 & $66-75$ & 0.000 \\
& Sesudah & 29,2 & & & \\
& Selisih & & & & \\
\hline 2. & Kemampuan psikomotor: & 33,88 & 4,83 & $26-46$ & 0.000 \\
& Sebelum & 57,12 & 6,46 & $45-68$ & \\
& Sesudah & 23,24 & & & \\
& Selisih & & & \\
\hline
\end{tabular}

Tabel 3. diketahui pada kelompok intervensi kemampuan keluarga aspek kognitif dan psikomotor dengan $p$ value 0,0001 artinya ada perbedaan yang bermakna kemampuan kognitif dan psikomotor pada kelompok intervensi sebelum dan sesudah dilakukan psikoedukasi keluarga. Kemampuan kognitif terdapat peningkatan dari sebelum perlakuan yaitu 40,28 menjadi 70,48 setelah perlakuan. Kemampuan psikomotor juga mengalami peningkatan dari sebelum perlakuan 33,88 menjadi 57,12 setelah perlakukan. Artinya pada kemampuan kognitif mengalami peningkatan dari kategori sedang menjadi kategori tinggi. Kemampuan psikomotor mengalami peningkatan dari kategori rendah menjadi kategori sedang.

Tabel 4. Analisis perbedaan kemampuan kognitif dan psikomotor keluarga pada kelompok kontrol sebelum dan sesudah pendidikan kesehatan keluarga di Kota Tasikmalaya 2012

\begin{tabular}{clcccc}
\hline No. & \multicolumn{1}{c}{ Variabel } & Mean & SD & Min-maks & P value \\
\hline 1. & Kemampuan Kognitif : & 40,48 & 7,36 & $31-58$ & 1,0 \\
& Sebelum & 40,48 & 7,36 & $31-58$ & \\
& Sesudah & & & & \\
\hline 2. & Kemampuan psikomotor: & 33,04 & 4,91 & $27-47$ & 1,0 \\
& Sebelum & 33,04 & 4,91 & $27-47$ & \\
& Sesudah & & & \\
\hline
\end{tabular}

Dari tabel 4. diketahui nilai $p$ value nya lebih dari 0,05 , sehingga dapat disimpulkan bahwa tidak ada perbedaan antara sebelum intervensi dan setelah intervensi pada kelompok kontrol. Sehingga semakin memperkuat perlunya perlakuan untuk mendapatkan psikoedukasi keluarga untuk dapat meningkatkan kemampuan kognitif dan psikomotor..

\section{Perbedaan kemampuan keluarga merawat klien HDR antara kelompok intervensi dan kelompok control}

Tabel 5. diketahui nilai $p$ valuenya 0,0001 artinya ada perbedaan yang bermakna pada kemampuan keluarga antara kelompok kontrol dengan kelompok intervensi setelah dilakukan pendidikan kesehatan keluarga. Meskipun mengalami kenaikan baik kemampuan kognitif maupun psikomotor, apabila dibandingan dengan rentang nilai maksimal kemampuan kognitif

76 dan kemampuan psikomotor 80, kenaikannya tidak mencapai $100 \%$. Kemampuan kognitif mencapai 92\% dan kemampuan psikomotor $71 \%$ pada kelompok intervensi. Demikian pula pada kelompok kontrol, kemampuan kognitif hanya mencapai 53\% dan kemampuan psikomotor $41 \%$. 
Tabel 5. Analisis perbedaan kemampuan kognitif dan psikomotor keluarga pada kelompok kontrol dan kelompok intervensi sesudah pendidikan kesehatan keluarga di Kota Tasikmalaya

\begin{tabular}{lcccc}
\hline \multicolumn{1}{c}{ Variabel } & Mean & SD & Min-maks & P value \\
\hline Kemampuan Kognitif : & & & & \\
Kelompok intervensi & 70,48 & 2,45 & $66-75$ & 0,0001 \\
Kelompok kontrol & 40,48 & 7,36 & $31-58$ & \\
Selisih & 30,00 & & & \\
\hline Kemampuan psikomotor: & & & & \\
Kelompok intervensi & 57,12 & 6,46 & $45-68$ & \\
Kelompok kontrol & 33,04 & 4,91 & $27-47$ & \\
Selisih & 24,08 & & & \\
\hline
\end{tabular}

\section{PEMBAHASAN}

\section{Pengaruh psikoedukasi keluarga terhadap kemampuan kognitif \\ Hasil analisis menunjukkan skor} kemampuan kognitif keluarga sebelum pemberian pendidikan kesehatan pada kelompok intervensi adalah 41,28 dan setelah mendapatkan pendidikan kesehatan keluarga menjadi 70,48 dengan $p$ value 0,000 . Artinya terdapat perbedaan yag bermakna pada kelompok intervensi antara sebelum dilakukan terapi psikoedukasi dengan setelah dilakukan terapi psikoedukasi keluarga. Apabila dikategorikan maka kemampuan kognitif sebelum tindakan pendidikan kesehatan keluarga berada pada kategori sedang, namun setelah dilakukan perlakuan psikoedukasi keluarga meningkat menjadi kategori tinggi. Pencapaian peningkatan kemampuan kognitif sebesar 92\% pada kelompok intervensi, dan pencapaian kemampuan kognitif pada kelompok kontrol sebesar $53 \%$ dari nilai maksimal kemampuan kognitif. Kemampuan kognitif akan membentuk cara berfikir seseorang untuk memahami faktor yang berkaitan dengan kondisinya dan berhubungan dengan perubahan perilaku (Notoatmodjo 2003).

Menurut Marsh (2000 dalam Stuart \& Sundeen 2006), program komprehensif dengan pemberdayaan keluarga memenuhi komponen informasi tentang gangguan jiwa dan sistem kesehatan jiwa, komponen keterampilan (komunikasi, resolusi terhadap konflik, pemecahan masalah, asertif, manajemen perilaku dan stress. Keterlibatan keluarga dalam pengambilan keputusan perawatan klien meningkatkan hasil dengan cara pendidikan dan dukungan keluarga untuk bekerjasama (Stuart \& Laraia, 2005). Keluarga dapat mengambil keputusan yang tepat apabila didukung dengan kemampuan kognitif yang baik tentang gangguan jiwa.

Pendidikan kesehatan keluarga dapat meningkatkan kemampuan keluarga karena dalam terapi mengandung unsur meningkatkan pengetahuan keluarga tentang penyakit, mengajarkan teknik yang dapat membantu keluarga untuk mengetahui gejala-gejala penyimpangan perilaku serta peningkatan dukungan bagi anggota keluarga itu sendiri. Tujuan program pendidikan ini adalah meningkatkan pencapaian pengetahuan keluarga tentang penyakit, mengajarkan keluarga bagaimana teknik pengajaran untuk keluarga dalam upaya membantu mereka melindungi keluarganya dengan mengetahui gejala-gejala perilaku dan mendukung kekuatan keluarga (Stuart \& Laraia, 2005).

\section{Pengaruh pendidikan kesehatan keluarga terhadap kemampuan psikomotor}

Mengubah perilaku terlebih dahulu harus dilakukan strategi untuk mengubah pikiran (kognitif), karena perubahan perilaku diawali dengan penambahan pengetahuan. Perubahan perilaku dapat dilakukan dengan tiga strategi (WHO dalam Notoadmodjo, 2003) yaitu menggunakan kekuatan/ 
dorongan, pemberian informasi dan diskusi. Sementara Sunaryo (2004 dalam Sari 2007) menyatakan bahwa perubahan perilaku dipengaruhi oleh faktor kebutuhan, motivasi, sikap dan kepercayaan. Pemberdayaan keluarga secara langsung yang didukung pengetahuan yang cukup dan sikap positif maka akan meningkatkan kemampuan keluarga untuk merawat klien.

Perubahannya yang terjadi pada kemampuan psikomotor tidak seperti pada kemampuan kognitif, karena untuk merubah perilaku atau kemampuan psikomotor memerlukan waktu yang lebih lama dibandingkan dengan perubahan pada kognitif. Ditambah dengan perawatan pada gangguan jiwa bersifat jangka panjang (Videbeck, 2008). Hal ini menunjukkan bahwa keterampilan tertentu dapat dilatih melalui proses belajar sehingga mengalami peningkatan, sehingga peningkatannya hanya dari kategori rendah ke kategori sedang. Peran keluarga didalam perubahan perilaku ini sangat menentukan karena menurut Stuart \& Sundeen (2005), keluarga dapat memberikan perasaan mampu atau tidak mampu, diterima atau ditolak.

\section{Pengaruh pendidikan kesehatan terhadap kelompok kontrol, kelompok intervensi}

Peningkatan kemampuan kognitif pada kelompok intervensi sebesar $92 \%$ dan pada kemampaun psikomotor sebesar $71 \%$. Sementara pada kelompok kontrol pencapaian kemampuan kognitif sebesar $53 \%$ dan kemampuan psikomotor $41 \%$ dari nilai maksimal kemampuan kognitif. Psikoedukasi keluarga merupakan salah satu bentuk terapi perawatan kesehatan jiwa keluarga dengan cara pemberian informasi dan edukasi melalui komunikasi yang terapeutik (Stuart \& Laraia, 2005). Komunikasi terapeutik sangat diperlukan dalam menghadapi klien dengan gangguan jiwa terutama yang mengalami harga diri rendah kronik (HDR). Harga diri rendah merupakan salah satu tanda negatif skizofrenia. Gejala negatif yang muncul pada pasien HDR yaitu sikap apatis, bicara jarang, dan respon emosional yang tumpul.
Klien mengalami penurunan dalam kemampuan untuk berinteraksi dengan orang lain dan lingkungan. Klien tidak percaya diri, merasa asing atau berbeda dari orang lain. Klien tidak percaya bahwa mereka adalah individu yang berharga, sehingga klien menghindari orang lain. Videbeck (2008), berpendapat meskipun gejala negatif tidak terjadi secara episodik seperti gejala positif tetapi gejala-gejala tersebut menyebabkan keluarga harus memberikan perhatian ekstra kepada pasien (meningkatkan kebutuhan untuk bantuan activity daily living) karena gejala negatif menetap lebih lama dan menjadi penghambat utama pemulihan dan perbaikan fungsi dalam kehidupan seharihari klien.

Penelitian Wardaningsih (2007) bertujuan untuk mengetahui pengaruh pendidikan kesehatan keluarga terhadap beban dan kemampuan keluarga dalam merawat klien dengan halusinasi di Kabupaten Bantul Yogyakarta. Hasil penelitian ditemukan adanya pengaruh yang bermakna dalam menurunkan beban keluarga dan meningkatkan kemampuan keluarga dalam merawat klien dengan halusinasi. Penelitian Sari (2009) bertujuan unuk mengetahui pengaruh psikoedukasi/ pendidikan kesehatan keluarga terhadap beban dan kemampuan keluarga dalam merawat klien pasung di Kabupaten Bireuen Nangro Aceh Darussalam. Hasil penelitian ditemukan adanya pengaruh yang bermakna meningkatkan kemampuan kognitif dan psikomotor keluarga dalam merawat klien dengan dipasung.

Pendidikan kesehatan keluarga dapat meningkatkan kemampuan keluarga karena dalam terapi mengandung unsur meningkatkan pengetahuan keluarga tentang penyakit, mengajarkan teknik yang dapat membantu keluarga untuk mengetahui gejala-gejala penyimpangan perilaku serta peningkatan dukungan bagi anggota keluarga itu sendiri. Tujuan program pendidikan ini adalah meningkatkan pencapaian pengetahuan keluarga tentang penyakit, mengajarkan 
keluarga bagaimana teknik pengajaran untuk keluarga dalam upaya membantu mereka melindungi keluarganya dengan

\section{KESIMPULAN}

Karakteristik keluarga klien dengan HDR adalah sebagai berikut: sebagian besar berusia lebih dari 44 tahun, mayoritas berpendidikan rendah, pendapatan keluarga pada kelompok kontrol lebih banyak di atas UMR, sementara pada kelompok intervensi lebih banyak dibawah UMR, mayoritas keluarga mempunyai pekerjaan, hubungan dengan klien mayoritas adalah keluarga inti (orang tua).

Pendidikan kesehatan menunjukkan perbedaan yang bermakna pada

\section{SARAN}

Dinas kesehatan Kota Tasikmalaya membuat kebijakan atau mengadakan pelatihan terkait program pelayanan kesehatan jiwa di Kota Tasikmalaya dengan meningkatkan peran serta keluarga untuk mengaktifkan pemberdayaan masyarakat dan menetapkan program pelayanan kesehatan jiwa masyarakat

\section{DAFTAR PUSTAKA}

Ariawan, I.(1998). Besar dan metode sampel pada penelitian kesehatan, Jakarta: FKM-UI. (tidak dipublikasikan).

Carson, V.B (2000). Mental health nursing: the nurse-patient. Journey Philadelphia: WB. Saunders Company

Chien T.W.,Wong F.K. (2007). A family psychoeducation group program for chinese people with schizophrenia in hongkong. Arlington

Dopp. P (2008). Single \& multi Family network interventions: AN integrative response to seious mental ilness.2009.

Fortinash, K.M. \& Holoday, P.A. (2004). Psychiatric mental health nursing. Third edition,, St. Louis Missouri: Mosby - Year Book Inc. mengetahui gejala-gejala perilaku dan mendukung kekuatan keluarga (Stuart \& Laraia, 2005).

kemampuan kognitif dan psikomotor keluarga dalam merawat klien dengan HDR antara sebelum dan sesudah dilakukan pendidikan kesehatan keluarga.

Pendidikan kesehatan keluarga menunjukkan perbedaan secara bermakna antara kelompok yang mendapatkan terapi psikoedukasi keluarga dengan kelompok yang tidak mendapatkan pendidikan kesehatan keluarga di Kota Tasikmalaya.

sebagai program utama dalam program pokok pelayanan Puskesmas. Puskesmas mengadakan frekuensi penyuluhan dalam forum keluarga yang sudah ada di setiap puskesmas untuk melakukan deteksi dini, penyuluhan sebagai upaya preventif dan promotif, serta melakukan pemulihan pada pasien dengan gangguan jiwa.

Fontaine, K.L (2009). Mental health nursing Sixth edition, new jersey: pearson education Inc

Goldenberg I \& Goldenberg H. (2004). Family therapi an overview. Sixth edition. United states: Thomson

Hamilasari, (2009). Pengaruh family psychoeducation therapy terhadap beban dan kemampuan keluarga dalam merawat klien pasung di kabupten bireuen nanggroe aceh darussalam, Tesis Jakarta. FIK. Tidak dipublikasikan. 